\title{
Moderasi Manacika Parisudha terhadap Pengaruh Skeptisme Profesional pada Deteksi Kecurangan
}

\author{
Anak Agung Ngurah Agung Kresnandra1 \\ Fakultas Ekonomi dan Bisnis \\ Universitas Udayana, Indonesia
}

\author{
I Wayan Gde Wahyu Purna Anggara² \\ Fakultas Ekonomi dan Bisnis \\ Universitas Udayana, Indonesia
}

Surel : ngurahagungkresnandra@unud.ac.id

\begin{abstract}
ABSTRAK
Penelitian ini bertujuan untuk mengetahui efek variabel moderasi Manacika Parisudha pada pengaruh skeptisme professional auditor terhadap deteksi kecurangan. Untuk mencapai tujuan penelitian, dikumpulkan data primer melalui penyebaran kuesioner yang telah lulus uji instrumen dengan responden 60 orang yang memiliki jabatan pengawas internal seperti auditor internal, akuntan dan perpajakan. Penelitian ini menggunakan metode quota sampling. Hipotesis diuji menggunakan analisis regresi moderasi atau Moderated Regression Analysis (MRA) Hasil penelitian menemukan bahwa Skeptisme Profesional Auditor berpengaruh positif dan signifikan terhadap Deteksi Kecurangan, dan Manacika Parisudha tidak memperkuat pengaruh positif Skeptisme Professional Auditor pada Deteksi Kecurangan.
\end{abstract}

Kata Kunci: Skeptisme Profesional Auditor; Manacika Parisudha; Deteksi Kecurangan.

\section{Manacika Parisudha's Moderation on the Effect of Professional Skepticism on Fraud Detection}

\section{ABSTRACT}

This study aims to determine the effect of the moderating variable Manacika Parisudha on the effect of professional auditor skepticism on fraud detection. To achieve the research objectives, primary data was collected through the distribution of questionnaires that had passed the instrument test with 60 respondents holding internal supervisory positions such as internal auditors, accountants and taxation. This research uses quota sampling method. The hypothesis was tested using Moderated Regression Analysis (MRA). The results found that Auditor Professional Skepticism had a positive and significant effect on Fraud Detection, and Manacika Parisudha did not strengthen the positive influence of Professional Auditor Skepticism on Fraud Detection.

Keywords: Auditor's Professional Skepticism; Manacika Parisudha; Fraud Detection.

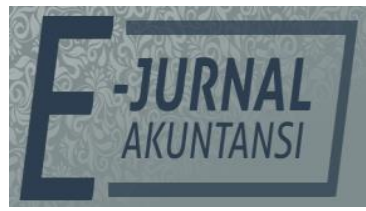

e-ISSN 2302-8556

Vol. 31 No. 6

Denpasar, Juni 2021 Hal. 1561-1576

DOI:

10.24843/EJA.2021.v31.i06.p17

PENGUTIPAN:

Kresnandra, A.A.N.A., \& Anggara, I W.G.W.P. (2021). Moderasi Manacika Parisudha terhadap Pengaruh Skeptisme Profesional pada Deteksi Kecurangan. E-Jurnal Akuntansi, 31(6), 1561-1576

RIWAYAT ARTIKEL:

Artikel Masuk:

30 Mei 2021

Artikel Diterima:

25 Juni 2021

Artikel dapat diakses : https://ojs.unud.ac.id/index.php/Akuntansi/index 


\section{PENDAHULUAN}

Transparency International (TI), sebuah lembaga survei internasional yang menggambarkan tingkat kecurangan yang terjadi di Indonesia sebagai salah satu negara dengan tingkat korupsi yang tinggi di dunia. Transparency International (TI) mengukur peringkat negara-negara tersebut berdasarkan CPI (Corruption Perception Index). Indeks ini memilikirentang nilai antara 0 sampai 100 dimana 0 mengindikasikan negara korupsi tertinggi dan 100 mengindikasikan negara terbersih. CPI Indonesia seperti yang terlihat pada Gambar 1, menunjukkan upaya pemberantasan korupsi yang berlangsung belum maksimal karena indeks yang tercatat belum mencapai indeks rata-rata yaitu nilai 50 netral.

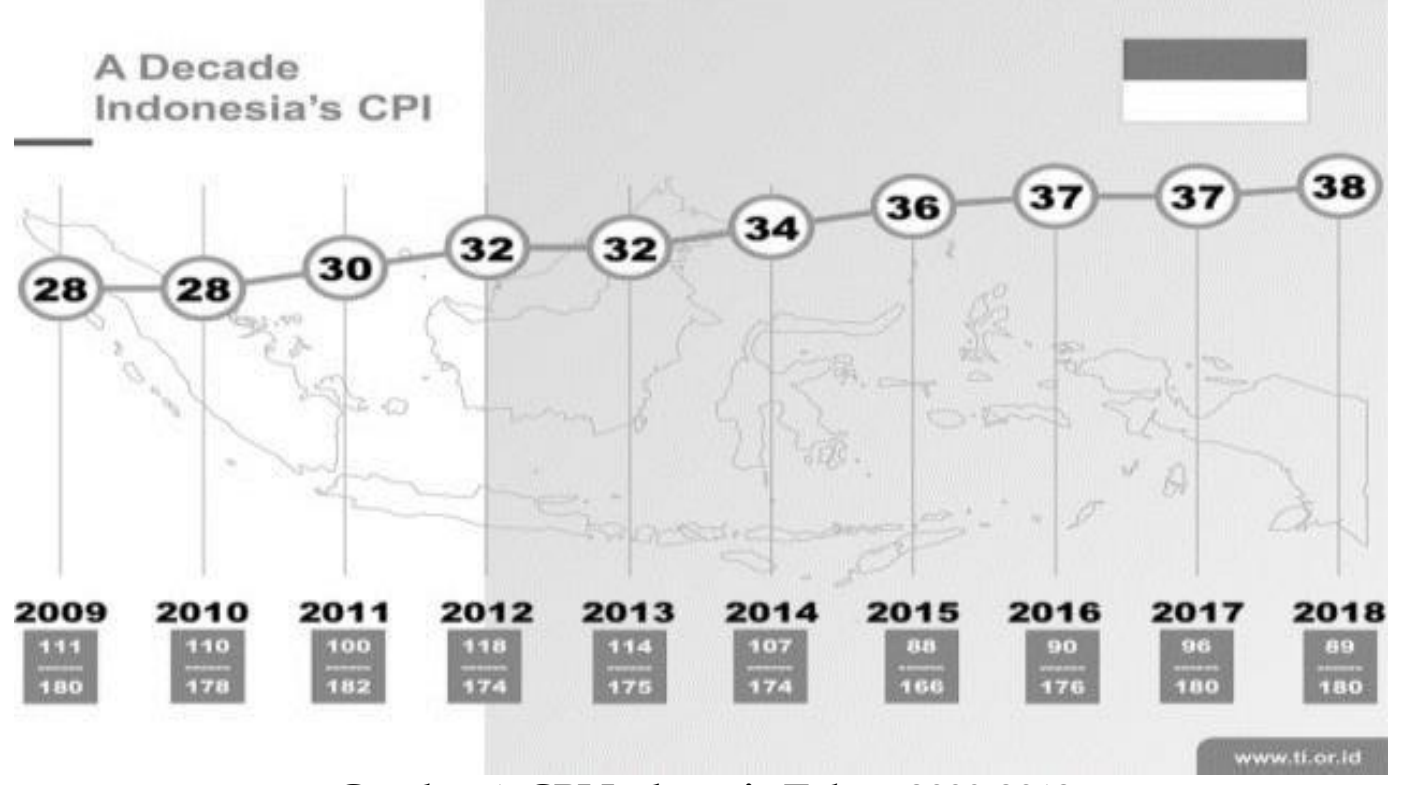

Sumber: CPI lindonesia, 2020

Kecurangan terjadi hampir diseluruh jenis organisasi atau perusahaan, baik instansipemerintah maupun swasta. Salah satu jenis perusahaan itu adalah hotel, dimana Provinsi Bali khususnya Kabupaten Badung Selatan adalah penyumbang pajak hotel terbesar se-Bali yang juga tidak luput akan praktik kecurangan. Mengutip berita dari Merdeka.com tanggal 9 Januari 2013, 10 hotel di Kabupaten Badung diduga menggelapkan pajak hingga puluhan miliar. Kecurangan seperti ini selain merugikan bagi pemerintah daerah, juga merugikan pihak hotel itu sendiri, karena nantinya perusahaan bisa menghadapi tuntutan hukum baik berupa denda hingga pidana. Jika kecurangan dilakukan secara sistematis dan melibatkan oknum internal maupun eksternal perusahaan, maka deteksi dan pengungkapan kecurangan berada pada auditor internal sebagai barrier pertama yang dapat mencegah kecurangan terjadi maka diperlukannya peran satandar audit untuk menjaga agar tidak terjadi kecurangan.

Standar Audit (SA) No. 240 menyatakan bahwa auditor yang melaksankan audit berdasarkan SA bertanggung jawab untuk memperoleh keyakinan memadai apakah laporan keuangan secara keseluruhan bebas dari kesalahan penyajian material, yang disebabkan oleh kecurangan atau kesalahan. Jika dalam proses pengauditan auditor menemukan adanya indikasi kecurangan maka auditor 
bertanggung jawab mengkomunikasikan dengan segera, hal tersebut kepada tingkat manajemen yang tepat, dengan tujuan untuk menginformasikankepada pihak yang memiliki tanggung jawab utama untuk mencegah dan mendeteksi kecurangan tentang hal - hal yang relevan dengan tanggung jawab mereka (SPAP, 2014: 240.1-14). Ada beberapa factor yang harus dimiliki seorang auditor untuk dapat mendeteksi kecurangan di sebuah perusahaan, salah satunya adalah skeptisme professional auditor.

Penelitian dari AAERs (Accounting and Auditing Releases) dalam Hartan \& Waluyo, (2016), SEC selaku pemegang otoritas saham pasar modal terbesar di Amerika Serikat selama periode Januari 1987-Desember 1997 menyatakan bahwa salah satu faktor penyebab terjadinya kegagalan auditor dalam mendeteksi kecurangan diakibatkan karena rendahnya tingkat skeptisme profesional dari seorang auditor. Berdasarkan hasil riset AAERs, sebanyak 24 kasus (60 persen) dari total 45 kasus kecurangan dalam laporan keuangan perusahaan, disebabkan karena auditor tidak menerapkan sikap skeptisme profesional yangmemadai.

Hasil-hasil riset terdahulu terkait pengaruh skeptisme profesional auditor terhadap kemampuan auditor dalam mendeteksi kecurangan masih menunjukan adanya gap penelitian. Hasil riset Hartan \& Waluyo, (2016), Rahmayani et al., (2014), Biksa \& Wiratmaja, (2016) serta (Mokoagouw et al., 2018), menyatakan bahwa, skeptisme professional berpengaruh positif terhadap kemampuan deteksi kecurangan. Hasil riset berbeda ditunjukan oleh penelitian Lovita, (2016), Rachman, (2017) dan Ranu \& Merawati, (2017) yang menyatakanbahwa skeptisme professional audit tidak berpengaruh terhadap kemampuan auditor dalam mendeteksi kecurangan. Inkonsistensi hasil ini diduga karena adanya faktor lain yang memengaruhi hubungan antara variabel bebas dengan variabel terikat. Govindarajan, (1986) menyatakan bahwa kemungkinan belum adanya kesatuan hasil penelitian tergantung faktor-faktor tertentu atau lebih dikenal dengan istilah faktor kontinjensi. Beberapa faktor kontingensi dapat diduga memoderasi pengaruh skeptisme terhadap deteksi kecurangan, salah satunya adalah manacika parisudha. Manacika parisudha merupakan salah satu bagian dari tri kaya parisudha yang harus diprioritaskan, karena pada dasarnya semua perkataan dan perbuatan bermula dari pikiran. Manacika parisudha menjadi cikal bakal dari sikap baik kita karena sikap yang baik akan keluar dari pikiran yang baik. Murda (2010) menjelaskan bahwa dari pikiran yang suci akan lahirlah perkataan suci, dengan adanya pikiran dan perkataan suci akan terwujudlah perbuatan suci. Penelitian ini berbeda dengan penelitian-penelitian terdahulu yang telah dikemukakan yaitu penelitian ini menggunakan manacika parisudha sebagai variabel moderasi dalam model penelitiannya.

Menurut Fishbein \& Ajzen, (1991) menggambarkan bahwa Teori Perilaku yang Direncanakan (Theory of Planned Behavior) adalah teori yang mengasumsikan bahwa manusia akan berperilaku sesuai dengan apa yang diinginkan oleh lingkungannya. Tujuan dan manfaat teori dalam konteks penelitian ini adalah untuk memahami pengaruh-pengaruh motivasi perilaku, baik kemauan individu itu sendiri maupun bukan kemauan dari individu tersebut. Menurut Kreshastuti (2014) dalam Purwanti \& Astika, (2017) menyatakan bahwa teori ini memiliki fungsi daritiga dasar determinan, yaitu Sikap Terhadap Perilaku (Attitude Toward 
the Behavior), Norma Subyektif (Subjective Norm) dan Persepsi Kontrol Perilaku (Perceived Behavioral Control).

Menurut Heider, (1958) teori atribusi merupakan suatu teori yang menjelaskan tentang penyebab atau motif seseorang baik dari faktor internal maupun eksternal yang memberikan pengaruh untuk melakukan suatu tindakan atau perilaku. Dalam penelitian ini, peneliti menggunakan teori atribusi, karena peneliti menganggap kemampuan dari seorang auditor untuk mengungkapkan suatu tindakan kecurangan dipengaruhi dari faktor internal yang dimiliki oleh auditor, seperti sikap skeptisme auditor tersebut untuk tidak mudah percaya serta selalu bersikap hati-hati terhadap pihak-pihak yang memiliki kepentingan dalam laporan kuangan sehingga laporan yang dihasilkan relevan dan andal walaupun dapat memberatkan salah satu pihak.

Kerangka konseptual merupakan konseptual tentang bagaimana teori berhubungan dengan berbagai faktor yang telah diidentifikasikan sebagai masalah penelitian dan mendefinisikan relevansi antara variabel independen dengan dependen sesuai dengan teori yang digunakan. Penelitian ini membahas tentang Moderasi Manacika Parisudha pada pengaruh skeptisme profesional auditor terhadap deteksi kecurangan.

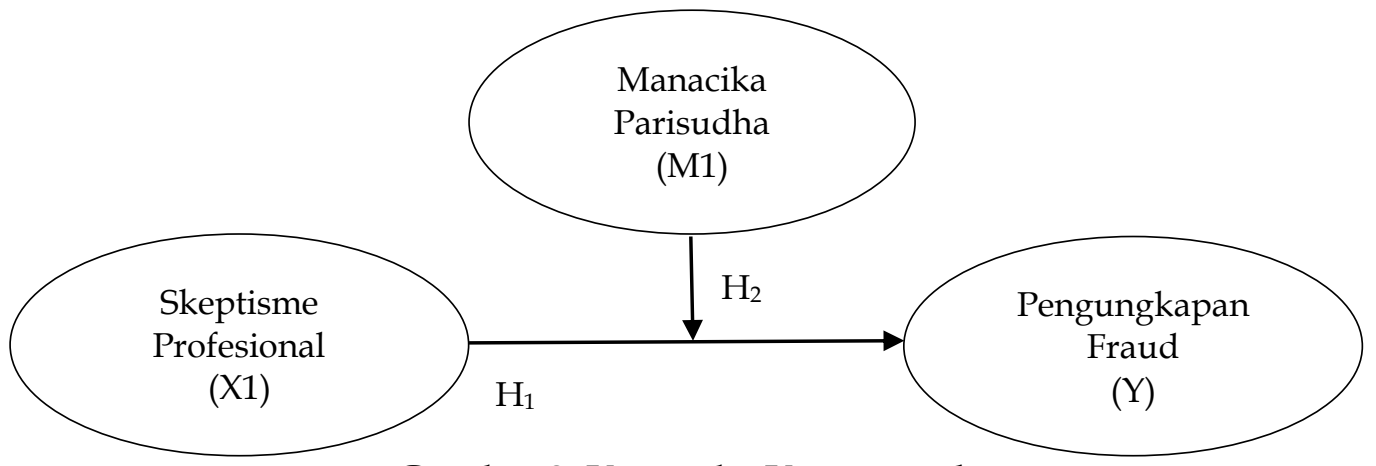

Gambar 2. Kerangka Konseptual

Sumber: Data Penelitian, 2020

Menurut Fitriana et al., (2020) dalam International Standards on Auditing menjelaskan bahwa skeptisme profesional auditor adalah penting untuk penilaian secara kritis terhadap bukti-bukti audit, yaitu auditor harus mempertanyakan keandalan dan relevansi dokumen-dokumen yang diperoleh dari manajemen dan mempertimbangkan kecukupan dan keandalan bukti tersebut. Auditor yang memiliki sikap skeptis yang memadai, akan mencoba memperoleh bukti-bukti yang cukup (sufficient) berupa butki fisik maupun hal-hal yang membuktikan atau dalam istilah auditing dikenal dengan nama evidence dan evidential matter. Melalui bukti yang cukup tersebut, seorang auditor yang memiliki sikap skeptic yang memadai akan lebih mudah dalam mendeteksi kecurangan. Pengaruh positif skeptisme terhadap deteksi kecurangan terlihat dari beberapa hasil-hasil riset terdahulu antara lain riset Hartan \& Waluyo, (2016) menemukan bahwa skeptisme berpengaruh positif terhadap deteksi kecurangan. Hasil riset ini juga didukung Rahmayani et al., (2014), Biksa \& Wiratmaja, (2016) serta (Mokoagouw et al., 2018), yang menyatakan bahwa, skeptisme professional berpengaruh positif terhadap kemampuan deteksi kecurangan. Berdasarkan rerangka konseptual dan hasilhasil riset empiris yang telah dipaparkan, maka dapat dikembangkan hipotesis 
penelitian sebagai berikut.

$\mathrm{H}_{1}$ : Skeptisme profesional auditor berpengaruh positif terhadap deteksi kecurangan.

Manacika parisudha merupakan konsep berpikir yang baik atau berpikir positif dalam tri kaya parisudha. Dalam Theory Reason Action (TRA) mengungkapkan bahwa keyakinan merupakan prediktor dari sikap, sehingga dapat disimpulkan bahwa pikiran menghasilkan sikap. Manacika parisudha menjadi cikal bakal dari sikap baik kita karena sikap yang baik akan keluar dari pikiran yang baik. Seseorang yang tidak bersikap baik tentu saja karena ia tidak mampu berpikir secara baik sehingga sikap yang menjadi cikal bakal seseorang tersebut dalam bertindak akan menjadi tidak baik pula (Indrayani et al., 2014).

Sikap skeptisme yang dimiliki oleh seorang auditor diperkuat lagi dengan kebeninganpikiran dalam bentuk Manacika Parisudha akan membebaskan dirinya dari pikiran-pikiranburuk untuk berbuat hal yang menguntungkan dirinya dan merugikan orang lain. Selain itusinergi antara sikap skeptic dan Manacika Parisudha ini akan menyebabkan auditor semakin obyektif dalam menilai bukti-bukti transaksi, sehingga kecurangan yang nyata terjadi akan lebih mudah dideteksi. Hasil riset Manuari et al., (2018) menemukan bahwa Manacika Parisudha memperlemah pengaruh sifat love of money (kecintaan terhadap uang yang berlebihan) pada sikap etis yang jika ditelusuri lebih lanjut, tindakan kecurangan yang dilakukan orang atau sekelompok orang dalam perusahaan merupakan tindakan yang sebagian besar disebabkan oleh sifat kecintaan yang berlebihan terhadap uang. Sehingga, jika dengan Manacika Parisudha seorang auditor dapat memperlemah kecintaan yang berlebih terhadap uang, maka tentunya akan berdampak pada proses audit yang lebih obyektif, sehingga kecurangan yang terjadi akan segera dapat dideteksi. Berdasarkan paparan kerangka teori yang telah dijelaskan, maka dapat dirumuskan hipotesis sebagai berikut.

$\mathrm{H}_{2}$ : Manacika Parisudha memperkuat pengaruh skeptisme professional auditor terhadapdeteksi kecurangan.

\section{METODE PENELITIAN}

Variabel-variabel yang dianalisis dalam penelitian ini terdiri atas satu variable bebas (skeptisme profesional),satu variabel moderasi (Manacika Parisudha), serta satu variable terikat (deteksi kecurangan), yang didefinisikan sebagai berikut.

Skeptisme profesional auditor adalah suatu sikap mental auditor yang selalu memiliki penilaian kritis terhadap suatu bukti keuangan tanpa obsesif mencurigakan atau skeptis pada hotel-hotel yang terdapat di Kabupaten Badung Selatan dengan tingkat akreditas berbintang 3. Sikap skeptis juga menggambarkan kehati-hatian dari auditor dalam mengaudit suatu laporan keuangan dengan mencari bukti-bukti laporan keuangan guna menghasilkan laporan audit yang relevan dan andal. Auditor selalu mempetanyakan bukti-bukti yang didapat selama proses audit mengenai keandalan bukti tersebut untuk menghindari terjadinya salah saji maupun kecurangan.

Menurut Hartan \& Waluyo, (2016) (Hartan \& Waluyo, 2016) Indikator yang digunakan untuk mengukur tingkat Skeptisme Profesional Auditor Internal antara lain, Questioning Mind (pikiran yang selalu bertanya), Suspension of Judgment 
(penundaan pengambilan keputusan), Search for Knowledge (pencarian informasi/pengetahuan), Interpersonal Understanding (pemahaman dalam diri seseorang), dan Self Confidence/Self Determination (kepercayaan diri).

Manacika parisudha merupakan salah satu bagian dari tri kaya parisudha. Mudera (1992) menyatakan definisi sederhana tri kaya parisudha terdiri dari manacika parisudha (penyucian pikiran/ berpikir yang baik), wacika parisudha (penyucian perkataan/berkata yang baik) dan kayika parisudha (penyucian perbuatan/ berbuat yang baik) pada hotel-hotel yang terdapat di Kabupaten Badung Selatan dengan tingkat akreditas berbintang 3. Dalam tri kayaparisudha, manacika parisudha inilah yang harus diprioritaskan, karena pada dasarnya semua hal bermula disini (Suhardana, 2007).

Sarasamusccaya sloka 80 menyebutkan "Mano hi mulam sarvesam indriyanam prawartate subhasubhavavasthasu karyam tat suvyavasthitam", yang berari pikiran itu adalah sumber indriya, yang menggerakkan perbuatan baik dan buruk. Karena itu pikiran itu patut dikendalikan secepatnya. Maka definisi operasional manacika parisudha dalam penelitian ini adalah berpikir yang baik.

Dalam penelitian ini peneliti membangun kuesioner dengan memulai dari menentukan konstruk-konstruk dari manacika parisudha berdasarkan sumber dari kitab sarasamusccaya sloka 74, 79, dan 80 yang membahas mengenai manacika parisudha. Sehingga dibangunlah 11 item pertanyaan mengenai manacika parisudha. Terdapat enam konstruk yang peneliti pakai untuk membangun 11 item pertanyaan yakni tidak iri hati, tidak mudah marah, pemaaf, tidak mudah putus asa, tidak berpikir curang dan percaya hukum karmaphala. Setelah dibangun 11 item pertanyaan, kuesioner ini diuji reliabilitas dan validitasnya.

Kemampuan auditor dalam mendeteksi kecurangan merupakan kemahiran atau keahlian seorang auditor untuk mendeteksi ada tidaknya kecurangan yang terdapat pada laporan keuangan. Kemampuan auditor dalam mendeteksi kecurangan dapat diukur dengandua indikator, antara lain, Pengetahuan tentang kecurangan dan Kesanggupan dalam tahap pendeteksian.

Populasi dalam penelitian ini adalah seluruh auditor internal yang bekerja pada hotelberbintang tiga di Kabupaten Badung Selatan yang tercatat dalam Badan Pusat Statistik Provinsi Bali yang berjumlah 45 hotel pada tahun 2016. Sampel dari penelitian ini adalah auditor internal yang bekerja pada dua puluh (20) hotel berbintang tiga terbaik di Kabupaten Badung Selatan.

Metode penentuan sampel yang digunakan dalam penelitian ini adalah quota sampling yang merupakan salah satu teknik nonrandom sampling. Pengumpulan data dilakukan secara langsung pada unit sampling sampai kuota tersebut terpenuhi dan pengumpulan data dihentikan. Kriteria tersebut adalah auditor internal yang bekerja pada dua puluh (20) hotel berbintang tiga di Kabupaten Badung Selatan.

Kuesioner disebarkan kepada Auditor Sepuluh Hotel Berbintang 3 di Kabupaten Badung Selatan. Dengan menggunakan skala likert, jawaban pilihan responden akan diberi nilai dengan skala poin 5 sebagai skor tertinggi dan skala poin 1 untuk skala poin terendah. Pengujian instrument penelitian dengan uji validitas dan reliabilitas. Teknik analisis data pada penelitian ini yaitu, statistic deskriptif, uji asumsi klasik, uji analisis regresi moderasi dengan MRA. Uji 
hipotesis (uji t), uji kelayakan model (uji f), koefisien determinasi ( $\left.\mathrm{R}^{2}\right)$ dan pengembangan model persamaan MRA prediksian PED/ $\hat{Y}$.

Setelah melakukan pengujian asumsi klasik terhadap sampel penelitian, kemudian akan dilakukan analisis data verifikatif dengan menggunakan teknik analisis regresi moderasi/Moderated Regression Analysis (MRA). Pengujian hipotesis ini dilakukan dengan menggunakan Statistical Product and Service Solution (SPSS) dengan tingkat signifikasi 5 persen $(\alpha=0,05)$. Dalam menguji hipotesis dikembangkan suatu persamaan untuk menyatakan hubungan antara variabel dependen, yaitu Deteksi Kecurangan (Y) dengan variabel independen, yaitu Skeptisme Profesional Auditor $\left(\mathrm{X}_{1}\right)$, dan interaksi dengan variable moderasi Manacika Parisudha $\left(\mathrm{M}_{1}\right)$. Pengujian hipotesis dengan analisis regresi linear berganda diformulasikan sebagai berikut.

$\mathrm{Y}=\mathrm{a}+\mathrm{b}_{1} \mathrm{X}_{1}+\mathrm{b}_{2} \mathrm{M}_{1}+\mathrm{b}_{3} \mathrm{X}_{1} \mathrm{M}_{1}+\varepsilon$

Keterangan:

$\mathrm{Y} \quad=$ Deteksi Kecurangan

a $\quad=$ Nilai Konstanta

$\mathrm{X}_{1} \quad=$ Skeptisme Profesional Auditor

$\mathrm{M}_{1} \quad=$ Manacika Parisudha

$\mathrm{b}_{1} \quad=$ Koefisien regresi variabel independen

$\mathrm{b}_{2} \quad=$ Koefisien regresi variable moderasi

$b_{3} \quad=$ Koefisien regresi interaksi $X_{1}$ dengan $M_{1}$

Setelah dilakukan input dan proses data menggunakan SPSS dapat diperoleh luaranatau informasi nilai konstanta dan nilai koefisien beta $\left(b_{1,2,3,4,5,6)}\right.$ masing-masing variabel: $X_{1}, M_{1}, M_{2}, X_{1} M_{1}, X_{1} M_{2}$. Selanjutnya, berdasarkan nilai konstanta dan nilai koefisien betadapat dikembangkan persamaan model MRA prediksian PED atau $\hat{Y}$, sebagai berikut.

$\hat{Y}=a+b_{1} X_{1}+b_{2} M_{1}+b_{3} M_{2}+b_{4} X_{1} M_{1}+b_{5} X_{1} M_{2}+\varepsilon$

\section{HASIL DAN PEMBAHASAN}

Kuesioner penelitian ini disebarkan pada hotel-hotel yang terdapat di Kabupaten Badung Selatan dengan tingkat akreditas berbintang 3. Kuesioner ini ditujukan untuk responden yang memiliki jabatan pengawas internal seperti auditor internal. Setelah dilakukan penyebaran kuesioner didapat 11 (sebelas) hotel dengan 60 orang responden yang bersedia berpartisipasi dalam penelitian ini. Dari 60 kuesioner yang dibagikan, semua kuesioner dapat diterima kembali dan semua kuesioner tersebut digunakan dalam penelitian ini karena semua syarat yang ditentukan untuk menjadi responden sudah dimiliki oleh semua responden yang berpartisipasi.

Berdasarkan Tabel 1, dapat dilihat bahwa responden dari 11 hotel yang berpartisipasi dalam pengisian kuesioner di Kabupaten Badung berjenis kelamin laki-laki sebesar 53,3 persen dan sisanya sebesar 46,7 persen merupakan responden perempuan. Dengan demikian dapat diketahui bahwa auditor internal hotel yang berpartisipasi dalam pengisian kuesioner di Kabupaten Badung mayoritas berjenis kelamin laki-laki.

Terdapat data yang memperlihatkan jenjang pendidikan yang dimiliki responden yang berpartisipasi dalam pengisian kuesioner dengan data responden 
yang memiliki jenjang pendidikan sarjana (S1) sebesar 66,7 persen dan sisanya memiliki jenjang pendidikan diploma (D1) sebesar 25 persen, dan SMA sebesar 8,3 persen. Dengan demikian dapat diketahui bahwa auditor internal dari 11 hotel yang berpartisipasi dalam pengisian kuesioner memilikijenjang pendidikan yang cukup tinggi dengan mayoritas responden merupakan tamatan dari jenjang pendidikan sarjana (S1).

Selain itu terdapat data pembagian posisi jabatan auditor internal dalam 11 hotel yang berpartisipasi dalam pengisian kuesioner. Dari data yang diperoleh dapat diketahui bahwa pembagian posisi auditor internal dalam setiap hotel cenderung merata sebanyak 2 orang Night Auditor, 1 orang Income Auditor, 1 orang Cost Control dan 1 orang Chief Accounting serta terdapat 5 hotel yang memiliki 1 orang Taxer.

Berikut adalah data demografi dari responden berdasarkan pengembalian kuesioneryang dibagikan dalam kategori jenis kelamin, jenjang pendidikan, dan jabatan responden.

Tabel 1. Karakteristik Responden Penelitian

\begin{tabular}{clrr}
\hline No & Karakteristik Responden & Jumlah (Orang) & Proporsi (\%) \\
\hline \multirow{2}{*}{1 Jenis Kelamin: } & & \\
Laki-Laki & 32 & 53.3 \\
& Perempuan & 28 & 46.7 \\
& Jumlah & 60 & 100 \\
& Jenjang Pendidikan: & & \\
& SMA & 5 & 8.3 \\
Diploma & 15 & 25.0 \\
S1 & 40 & 66.7 \\
Jumlah & 60 & 100.0 \\
Jabatan: & & \\
NA1 & 11 & 18.3 \\
NA2 & 11 & 18.3 \\
IA & 11 & 18.3 \\
CC & 11 & 18.3 \\
CA & 11 & 18.3 \\
Taxer & 5 & 8.3 \\
Jumlah & 60 & 100.0 \\
\hline
\end{tabular}

Sumber: Data Penelitian, 2020

Jumlah data responden yang digunakan untuk menguji validitas berjumlah 60 data dengan tingkat signifikansi 5 persen sehingga mendapatkan nilai $r_{\text {tabel }}$ sebesar 0,254 . Kriteria pengujian apabila nilai pearson correlation $<r_{\text {tabel }}$ maka item pernyataan dikatakan tidak valid, sedangkan apabila nilai pearson correlation $>r_{\text {tabel }}$ maka item pernyataan dikatakan valid. Apabila nilai pearson correlation $=r_{\text {tabel }}$, maka untuk pengujian validitas data dapat diperhatikan di tingkat signifikansinya yang tidak boleh melebihi 0,05 (sig $\leq 0,05$ ).

Pada Tabel 2, dapat diketahui bahwa semua pernyataan dalam variabel Skeptisme Profesional memiliki nilai pearson correlation atau nilai $\mathrm{r}_{\text {hitung }}$ lebih besar dari nilai $r_{\text {tabel }}$ 0,254 dengan tingkat signifikansi kurang dari 0,05. Maka semua pernyataan tersebut dikatakan valid dan dapat dilanjutkan untuk penelitian. Satu dari delapan item pertanyaan untuk mengukur variabel Manacika Parisudha tidak memenuhi kriteria uji validitas yaitu item pertanyaan nomor 7 (MP7). Pertanyaan 
MP7 selanjutnya akan dihilangkan pada pengujian selanjutnya. Semua pernyataan dalam variabel Pengungkapan Kecurangan memiliki nilai pearson correlation atau nilai $r_{\text {hitung }}$ lebih besar dari nilai $r_{\text {tabel }} 0,254$ dengan tingkat signifikansi kurang dari 0,05. Maka semua pernyataantersebut dikatakan valid dan dapat dilanjutkan untuk penelitian. Berikut adalah hasil pengujian reliabilitasvariabel skeptisme profesional, manacika parisudha danpengungkapan kecurangan sebagai berikut.

Tabel 2. Hasil Uji Validitas Skeptisme Profesional

\begin{tabular}{cccc}
\hline Item & Pearson Corelation & Sig. & Keterangan \\
\hline QM1 & 0,726 & 0,000 & Valid \\
QM2 & 0,739 & 0,000 & Valid \\
SOJ1 & 0,663 & 0,000 & Valid \\
SOJ2 & 0,432 & 0,001 & Valid \\
SFR1 & 0,485 & 0,000 & Valid \\
SFR2 & 0,506 & 0,000 & Valid \\
SFR3 & 0,576 & 0,000 & Valid \\
IU1 & 0,608 & 0,000 & Valid \\
IU2 & 0,562 & 0,000 & Valid \\
IU3 & 0,524 & 0,000 & Valid \\
SD1 & 0,453 & 0,000 & Valid \\
SD2 & 0,492 & 0,000 & Valid \\
MP1 & 0,586 & 0,000 & Valid \\
MP2 & 0,727 & 0,000 & Valid \\
MP3 & 0,712 & 0,000 & Valid \\
MP4 & 0,638 & 0,000 & Valid \\
MP5 & 0,645 & 0,000 & Valid \\
MP6 & 0,786 & 0,000 & Valid \\
MP7 & 0,225 & 0,000 & Tidak Valid \\
MP8 & 0,567 & 0,000 & Valid \\
Competence 1 & 0,779 & 0,000 & Valid \\
Competence 2 & 0,598 & 0,000 & Valid \\
Competence 3 & 0,670 & 0,000 & Valid \\
Ability 1 & 0,689 & 0,000 & Valid \\
Ability 2 & 0,655 & 0,000 & Valid \\
Ability 3 & 0,678 & 0,000 & Valid \\
\hline
\end{tabular}

Sumber: Data Penelitian, 2020

Pada Tabel 3, dapat diketahui bahwa nilai cronbach's alpha semua variabel lebihbesar dari 0,6. Maka dapat diketahui bahwa semua item dalam setiap variabel dapatdikatakan reliabel dan dapat dilanjutkan untuk dilakukan pengujian.

\section{Tabel 3. Hasil Uji Reliabilitas}

\begin{tabular}{ccr}
\hline Variabel & Cronbach's & \\
& Alpha & Keterangan \\
\hline Skeptisme Profesional Auditor & 0.807 & Reliabel \\
Manacika Parisudha & 0,820 & Reliabel \\
Pengungkapan Kecurangan & 0.800 & Reliabel \\
\hline
\end{tabular}

Sumber: Data Penelitian, 2020

Uji Normalitas bertujuan untuk menguji apakah dalam sebuah model regresi, variabel terikat dan variabel bebas atau keduanya memiliki distribusi normal atau tidak. Model regresi yang baik adalah model regresi yang memiliki 
distribusi data normal atau yang mendekati normal. Pengujian normalitas data dalam penelitian ini dilakukan dengan menggunakan statistik Kolmogorov-Smirnov dengan bantuan program SPSS 22 For Windows. Distribusi data dinyatakan normal apabila nilai signifikansi probabilitas pengujian yang lebih besar dari level signifikansi (a) 0,05 (Asymp. Sig > 0,05). Berikut ini adalah hasil pengujian normalitas data dengan menggunakan aplikasi SPSS 22 For Windows sebagai berikut.

Tabel 4. Hasil Uji Normalitas

\begin{tabular}{lrr}
\hline & & $\begin{array}{c}\text { Unstandardized } \\
\text { Residual }\end{array}$ \\
\hline $\mathrm{N}$ & & \\
Normal Parameters ${ }^{a, b}$ & Mean & .0000000 \\
& Std. & \\
Most Extreme & Deviation & 1,553505 \\
Differences & Absolute & .097 \\
& Positive & .097 \\
Test Statistic & Negative & -.097 \\
Asymp. Sig. (2-tailed) & & .097 \\
\hline
\end{tabular}

Sumber: Data Penelitian, 2020

Berdasarkan Tabel 4, dapat diketahui bahwa jumlah sampel yang digunakan berkurang menjadi 48 dari 60 sampel. Hal ini dikarenakan eliminasi data pengganggu (outlier) yang menyebabkan distribusi data tidak normal. Setelah outlier dieliminasi kemudian barulah diuji normalitasnya. Hasil uji yang diperoleh dengan metodeOne-Sample Kolmogorov-Smirnov menunjukkan hasil Asymp. Sig sebesar 0,200. Nilai trsebut lebih besar dibandingkan dengan level signifikansi a sebesar 0,05. Jadi dapat diketahui bahwa variabel Skeptisme Profesional Auditor dan Manacika Parisudha memiliki distrbusi data normal yang digambarkan dengan taraf Asymp.Sig (2-tailed) sebesar 0,305 lebih besar daripada taraf level signifikansi yang ditentukan (a)sebesar 0,05 $(0,200>0,05)$.

Tabel 4. Hasil Uji Multikolinearitas

\begin{tabular}{llcc}
\hline \multirow{2}{*}{ Model } & \multicolumn{2}{c}{ Collinearity Statistics } \\
\cline { 2 - 3 } & \multicolumn{2}{c}{ Tolerance } & VIF \\
\hline $1 \quad$ Constant $)$ & 0,563 & 1,775 \\
Skeptisme Profesional Auditor & 0,888 & 1,126 \\
$\quad$ Manacika Parisudha & &
\end{tabular}

Sumber: Data Penelitian, 2020

Uji Multikolinearitas bertujuan untuk menguji apakah dalam model regresi terdapathubungan multikolinearitas antara variabel bebas (independen) atau tidak. Model regresi yang baik seharusnya tidak terjadi multikolinearitas antara variabel bebas (independen). Untuk mendeteksi multikolinearitas dapat dilihat dari nilai Tolerance dan Variance Influence Factor dari hasil perhitungan regresi linear berganda menggunakan aplikasi SPSS22 For Windows. Jika nilai Tolerance > 0,10 dan jika nilai VIF $<10$ maka dapat diartikan tidak terdapat multikolinearitas begitu pula sebaliknya jika nilai Tolerance $<0,10$ dan jika nilai VIF $>10$ maka dapat diartikan terdapat multikolinearitas. Berikut merupakan hasil ujimultikolinearitas dengan menggunakan aplikasi SPSS 21 For Windows. 
Berdasarkan Tabel 4, dapat diketahui bahwa hasil Tolerance untukvariabel skeptisme profesional auditor dan manacika parisudha secara berurutan sebesar 0,563, dan 0,888. Begitu pula dengan nilai VarianceInfluence Factor (VIF) sebesar 1,775, dan 1,126. Hasil Tolerance tersebut memiliki nilai yang lebih besar dari nilai minimal yaitu sebesar 0,10 dan untuk nilai Variance Influence Factor (VIF) lebih kecil dari nilai batas yaitu sebesar 10. Berdasarkan hasil tersebut dapat diketahui bahwa dalam model regresi tersebut tidak terjadi multikolinearitas.

Uji heteroskedastisitas bertujuan untuk menguji apakah dalam model regresi terjadi ketidaksamaan variance dari residual satu pengamatan ke pengamatan lainnya. Model regresi yang baik adalah model regresi yang tidak terdapat gejala heteroskedastisitas. Pengujian ini dapat dianalisis melalui uji Glesjer Test yaitu dengan meregresi nilai absoluteresidual model yang diestimasi terhadap variabel-variabel independen denganmemperhatikan nilai t-statistik dan signifikansinya. Berikut adahal hasil uji Gletser Test dengan menggunakan aplikasi SPSS 22 For Windows sebagai berikut.

Tabel 5. Hasil Uji Heteroskedastisitas

\begin{tabular}{ccc}
\hline Variabel & Sig & Kesimpulan \\
\hline Skeptisme Profesional Auditor & 0,067 & Tidak Terjadi Heteroskedastisitas \\
Manacika Parisudha & 0,659 & Tidak Terjadi Heteroskedastisitas \\
\hline
\end{tabular}

Sumber: Data Penelitian, 2020

Berdasarkan Tabel 5, dapat diketahui bahwa pada variabel Skeptisme Profesional Auditor, dan Manacika Parisudha tidak terjadi gejala heteroskedastisitas. Pernyataan tersebut dapat dilihat dari nilai signifikansi variabel Skeptisme Profesional Auditor sebesar 0,067 lebih besar dari nilai signifikansi a 0,05, begitu pula dengan nilai signifikansi variabel Manacika Parisudha sebesar 0,659 lebih besar dari nilai signifikansi a 0,05. Berikut merupakan hasil dari pengujian analisis kelayakan model (Uji F) dengan menggunakan aplikasi SPSS Version 22 For Windows sebagai berikut.

Tabel 6. Uji Kelayakan Model (Uji F)

\begin{tabular}{|c|c|c|c|c|c|c|}
\hline \multicolumn{2}{|c|}{ Model } & Sum of Squares & Df & Mean Square & $\mathrm{F}$ & Sig. \\
\hline \multirow[t]{3}{*}{1} & Regression & 329,300 & 5 & 65,860 & 78,629 &, $000^{\mathrm{b}}$ \\
\hline & Residual & 35,179 & 42 & ,838 & & \\
\hline & Total & 364,479 & 47 & & & \\
\hline
\end{tabular}

Sumber: Data Penelitian, 2020

Berdasarkan Tabel 6, nilai $p$ value uji $\mathrm{F}$ adalah sebesar 0,000 yang lebih kecil dari nilai alpha $0,05(0,000<0,05)$, maka dapat diartikan bahwa variabel bebas skeptisme professional, variabel moderasi Manacika Parisudha, serta variabel interkasi moderasi 1 dan 2, memiliki kemampuan untuk menerangkan variasi variabel terikat pengungkapan kecurangan atau dapat diartikan juga bahwa model telah layak untuk dilakukan penelitian lebih lanjut.

Berdasarkan Tabel 7, dapat dilihat nilai Adjusted $R$ Square sebesar 0,653 atau 65,3 persen yang memiliki arti bahwa variabel bebas dan moderasi yang digunakan dalam model penelitian dapat menjelaskan variasi perubahan variabel terikat sebesar 65,3 persen, dan sisanya sebesar 34,7 persen dipengaruhi oleh variabel lain di luar penelitian. Dari Tabel 7, jugadiperoleh nilai koefisien korelasi (R) sebesar 0,651, menurut Sugiyono, (2017), nilaikoefisien korelasi yang berkisar 
antara 0,80-1,00 termasuk ke dalam kategori berkorelasi sangat tinggi. Berikut ini adalah tabel yang menampilkan hasil uji $\mathrm{T}$ atau pengujian hipotesis penelitian.

Tabel 7. Uji T (Uji Hipotesis)

\begin{tabular}{|c|c|c|c|c|c|c|c|}
\hline \multirow{2}{*}{\multicolumn{2}{|c|}{ Model }} & & \multicolumn{5}{|c|}{ Standardized } \\
\hline & & & $\mathrm{B}$ & Std. Error & $\frac{\text { Coefficients }}{\text { Beta }}$ & $\mathrm{t}$ & Sig. \\
\hline 1 & (Constant) & & 39,245 & 42,547 & & 0,922 & 0,362 \\
\hline & $\mathrm{X} 1$ & & 0,642 & 0,672 & 0,677 & 2,109 & 0,046 \\
\hline & M1 & & 0,565 & 0,626 & 0,757 & 2,118 & 0,045 \\
\hline & M2 & & 0,936 & 1,374 & 0,063 & 1,626 & 0,170 \\
\hline & X1_M1 & & 0,457 & 0,549 & 1,202 & 2,655 & 0,033 \\
\hline & X1_M2 & & 0,016 & 0,082 & 0,871 & 1,845 & 0,097 \\
\hline \multicolumn{2}{|c|}{ F hitung } & : & 78,629 & & & & \\
\hline \multicolumn{2}{|c|}{$\mathrm{Sig}$} & : & $0,000^{b}$ & & & & \\
\hline \multicolumn{2}{|c|}{ Adjusted $\mathrm{R}^{2}$} & : & 0,625 & & & & \\
\hline
\end{tabular}

Sumber: Data Penelitian, 2020

Berdasarkan Tabel 7, terdapat beberapa hasil yang dapat dijelaskan sebagai berikut. Nilai konstanta sebesar 39,245 yang berarti jika variabel bebas dan moderasi tidakberubah atau 0, makan variabel Deteksi Kecurangan (Y) akan sebesar 39,245.

Variabel $X_{1}$ (Skeptisme Profesional Auditor) nilai beta sebesar 0,642 dan bertanda positif, serta nilai $p$ value sebesar 0,046 yang lebih kecil dari alpha 0,05 $(0,046<0,05)$, keputusan menolak $\mathrm{H}_{0}$ dan menerima $\mathrm{H}_{1}$. Ini berarti Skeptisme Profesional Auditor berpengaruh positif dan signifikan terhadap Deteksi Kecurangan. Variabel $\mathrm{M}_{1}$ (Manacika Parisudha) memiliki nilai beta sebesar 0,936 dan bertanda positif, serta nilai $p$ value sebesar 0,170 yang lebih besar dari alpha 0,05 $(0,170>0,05)$, keputusan menerima $\mathrm{H0}$ dan menolak $\mathrm{H}_{1}$. Ini berarti Manacika Parisudha berpengaruh positif namun tidak signifikan terhadap Deteksi Kecurangan. Interaksi variabel bebas Skeptisme Profesional Auditor dengan variabel moderasi Manacika Parisudha $\left(\mathrm{X}_{1} \_\mathrm{M}_{1}\right)$ mendapatkan nilai beta sebesar 0,016 dan $p$ value sebesar 0,097 yang lebih besar dari alpha 0,05 $(0,097>0,05)$, keputusan menerima $\mathrm{H}_{0}$ dan menolak $\mathrm{H}_{2}$. Ini berarti Manacika Parisudha tidak memperkuat pengaruh positif Skeptisme Profesional Auditor pada Deteksi Kecurangan.

Berdasarkan hasil uji $\mathrm{T}$ dengan menggunakan teknik analisis regresi moderasi(MRA) yang disajikan pada Tabel 7, dapat disusun persamaan regresi prediksian yang baru yaitu sebagai berikut.

$$
\mathrm{Y}=39,245+0,642(\mathrm{X} 1)+0,565(\mathrm{M} 1)+0,457\left(\mathrm{X} 1 \_\mathrm{M} 1\right)+\varepsilon
$$

Berdasarkan hasil pengujian yang dapat diperhatikan pada Tabel 7, didapatkan nilai $p$ value 0,046 lebih kecil dari nilai alpha sebesar $0,05(0,046<0,05)$ sehingga hipotesis alternative satu $\left(\mathrm{H}_{1}\right)$ yang berbunyi Skeptisme Profesional Auditor berpengaruh positif terhadap Deteksi Kecurangan diterima.

Menurut Heider, (1958) teori atribusi merupakan suatu teori yang menjelaskan tentang penyebab atau motif seseorang baik dari faktor internal maupun eksternal yang memberikan pengaruh untuk melakukan suatu tindakan atau perilaku. Fishbein \& Ajzen, (1991) menggambarkan bahwa Teori Perilaku yang Direncanakan (Theory of Planned Behavior) adalah teori yang mengasumsikan 
bahwa manusia akan berperilaku sesuai dengan apa yang diinginkan oleh lingkungannya.

Hal ini menunjukkan bahwa variabel skeptisme profesional berpengaruh signifikan pada kemampuan deteksi kecurangan pada hotel berbintang 3 di Kabupaten Badung Selatan. Ini berarti semakin tinggi sikap skeptis seorang auditor di hotel berbintang 3 di Kabupaten Badung Selatan maka akan semakin tinggipula kemampuan auditor tersebut dalam mendeteksi kecurangan. Hasil penelitian ini sekaligus mengonfrimasi hasil-hasil riset terdahulu yang melihat pengaruh positif skeptisme terhadap deteksi kecurangan antara lain riset Rahmayani et al., (2014), Hartan \& Waluyo, (2016), Biksa \& Wiratmaja, (2016) serta (Mokoagouw et al., 2018), yang menyatakan bahwa, skeptisme professional berpengaruh positif terhadap kemampuan deteksi kecurangan.

Berdasarkan hasil pengujian yang dapat diperhatikan pada Tabel 7, didapatkan nilai $p$ value variabel interaksi Skeptisme Profesional Auditor dengan Manacika Parisudha sebesar 0,097 lebih besar dari nilai alpha sebesar 0,05 $(0,033<0,05)$ sehingga hipotesis alternative satu $\left(\mathrm{H}_{2}\right)$ yang berbunyi manacika parisudha memperkuat pengaruh skeptismeprofessional auditor terhadap deteksi kecurangan ditolak. Ini berarti baik buruknya pikiran seorangauditor tidak akan berpengaruh dalam memperkuat sikap skeptis seorang auditor yang terhadap kemampuannya mendeteksi kecurangan. Hasil ini sekaligus menolak hasil riset yang dilakukan (Manuari et al., 2018).

Penyebab manacika parisudha gagal memperkuat pengaruh skeptisme professional auditor terhadap deteksi dapat dikaitkan dari hasil jawaban kuesioner responden. Jawaban responden untuk mengukur Manacika Parisudha, ternyata lebih banyak responden mempersepsikan pertanyaan-pertanyaan untuk mengukur manacika parisudha dikisaran 3 dan 4 dengan rata-rata sebesar 3,79 (masih jauh untuk mencapai nilai 5), artinya auditor di Hotel Bintang 3 Kabupaten Badung Selatan masih mempersepsikan berpikir yang baik atau manacika parisudha adalah hal yang perlu ada, namun bukan menjadi suatu hal yang teramat penting dalam kegiatan audit. Jika seorang auditor tidak berpikir dengan baik/positif, tentunya akan sangat rentan dengan tekanan dari pihak eksternal maupun internal dari dalam diri sehingga akan mengurangi obyektifitasnya dalam memeriksa dan mendeteksi kecurangan. Untuk itu auditor seharusnya memerlukan pikiran yang baik(manacika parisudha) untuk dapat menghindarkan auditor dari tekanan-tekanan maupun hal-hal lain yang dapat mengurangi obyektifitasnya tersebut. Hasil penelitian sejalan dengan tori atribusi dan menurut Heider, (1958) teori atribusi merupakan suatu teori yang menjelaskan tentang penyebab atau motif seseorang baik dari faktor internal maupun eksternal yang memberikan pengaruh untuk melakukan suatu tindakan atau perilaku. Fishbein \& Ajzen, (1991) menggambarkan bahwa Teori Perilaku yang Direncanakan (Theory of Planned Behavior) adalah teori yang mengasumsikan bahwa manusia akan berperilaku sesuai dengan apa yangdiinginkan oleh lingkungannya.

\section{SIMPULAN}

Berdasarkan uraian yang telah dijelaskan sebelumnya maka dapat diperoleh kesimpulan sebagai berikut: Kehati-hatian pengawas internal yang dijelaskan 
melalui sikap skeptisme profesional berpengaruh positif dan signifikan pada kemampuan auditor internal dalam mendeteksi kecurangan pada hotel berbintang 3 ke atas di Kabupaten Badung Selatan. Tingginya skeptisme professional yang dimiliki auditor internal di hotel berbintang 3 ke atas Kabupaten Badung Selatan menyebabkan auditor internal tersebut lebih mudah dalam mendeteksi kecurangan (kecurangan) yang terjadi di perusahaannya.

Manacika Parisudha masih dipersepsikan sebagai suati hal yang perlu ada namun belum sebagai sesuatu hal yang wajib dimiliki seorang auditor internal Hotel berbintang 3 di Kawasan Badung Selatan. Hal ini menyebabkan auditor internal tersebut akan sangat rentan dengan tekanan-tekanan yang datang baik dari pihak eksternal seperti tekanan dari atasannya, maupun internal dari dalam diri individu untuk melakukan tindak kecurangan sehingga bukannya menemukan kecurangan namun bisa jadi auditor tersebut nantinya akan menjadi bagian bahkan pelaku kecurangan itu sendiri.

Berdasarkan uraian yang telah dijelaskan sebelumnya maka dapat diperoleh saran sebagai berikut: Bagi auditor internal, sebaiknya auditor internal selalu berpikiran yang positif/baik seperti jujur dan obyektif dalam setiap pelaksanaan audit di perusahaan masing-masing. Hal ini bertujuan agar terhindar dari pikiranpikiran yang tidak baik seperti menutup-nutupi kecurangan yang terjadi atau bahkan ikut menjadi bagian dalam kecurangan yangterjadi di perusahaan. Pihak manajemen dan perusahaan memberikan akses kepada auditor internal untuk memperoleh semua bukti keuangan yang diperlukan dalam melakukan proses auditing agar hasil keputusan laporan keuangan relevan dengan keadaan sebenarnya. Selain itu sebaiknya perusahaan mendukung dengan membangun iklim bekerja yang baik agar dapat menumbuhkan sifat skeptic, independendan pikiran-pikiran positif bagi karyawannya terutama bagi auditor internal perusahaannya.

Hasil penelitian ini diharapkan dapat menambah ilmu pengetahuan dan wawasan serta dapat memperkaya kepustakaan mengenai pengaruh skeptisme professional, dan Manacika Parisudha pada kemampuan pengawas internal dalam mendeteksi kecurangan yang dapat digunakan sebagai referensi untukpenelitian selanjutnya. Sebaiknya penelitian ini dilanjutkan dengan menambah jumlah responden dan memperluas area penyebaran kuesioner agar tidak hanya di Badung Selatan saja, sehingga hasil yang didapatkan nantinya bisa lebih bervariasi/beragam

\section{REFERENSI}

Biksa, I. A. I., \& Wiratmaja, I. D. N. (2016). Pengaruh Pengalaman, Indepedensi, Skeptisme Profesional Auditor Pada Pendeteksian Kecurangan. E-Jurnal Akuntansi, 17(3), 2384-2415. https://ojs.unud.ac.id/index.php/Akuntansi/article/view/24873

Fishbein, M., \& Ajzen, I. (1991). The Influence of Attitudes on Behavior. The Handbook of Attitudes, 173-222.

Fitriana, R., Nasution, D., \& Amyel, A. (2020). Pengaruh Konten Travel Blogger Terhadap Kunjungan Wisatawan Domestik Ke Sumbawa. Lontar: Jurnal Ilmu Komunikasi, 8(1). https://doi.org/doi.org/10.30656/lontar.v8i1.2086

Govindarajan, V. (1986). Impact of Participation in the Budgetary Process on 
Managerial Attitudes and Performance: Universalistic and Contingency Perspectives. Decision Sciences, 17(4), 496-516. https://doi.org/10.1111/j.1540-5915.1986.tb00240.x

Hartan, T. H., \& Waluyo, I. (2016). Pengaruh Skeptisme Profesional, Independensi Dan Kompetensi terhadap Kemampuan Auditor Mendeteksi Kecurangan (Studi Empirispada Inspektorat Daerah Istimewa Yogyakarta). Profita : Kajian Ilmu Akuntasni, 4(3). http://journal.student.uny.ac.id/ojs/index.php/profita/article/view/5626 Heider, F. (1958). The Psychology of Interpersonal Relations. New York: Wiley.

Indrayani, P. S., Arini, N. W., \& Rati, N. W. (2014). Pengaruh Skeptisme Profesional, Independensi Dan Kompetensi Terhadap Kemampuan Auditor Mendeteksi Kecurangan (Studi Empiris Pada Inspektorat Daerah Istimewa Yogyakarta). Jurnal Mimbar PGSD, 2(1). https://doi.org/10.23887/jjpgsd.v2i1.2545

Lovita, L. (2016). Pengaruh Skeptisisme Profesional Auditor terhadap Kemampuan Auditor Mendeteksi Kecurangan (Studi Pada Badan Pemeriksa Keuangan Perwakilan DIY). UAJN's Library, 1-15. https:/ / doi.org/http:/ /ejournal.uajy.ac.id/id/eprint/10317

Manuari, I. A. R., Mimba, N. P. S. H., \& Dwirandra, A. A. N. B. (2018). The Effect Of Love Of Money On Ethics With Manacika Parisudha As Moderating Variables. International Journal of Economics, Commerce and Managemen, VI(8), 355-375. http://www.ijecm.co.uk/wp-content/uploads/2018/08/6824.pdf

Mokoagouw, M., Kalangi, L., \& Gerungai, N. (2018). Pengaruh Skeptisme Profesional dan Pengalaman Auditor Terhadap Kemampuan Auditor Eksternal Dalam Mendeteksi Kecurangan (Survei Pada Auditor BPK RI Perwakilan Sulawesi Utara. Going Concern: Jurnal Riset Akuntansi, 13(2), 261272. https://doi.org/10.32400/gc.13.02.19267.2018

Purwanti, I. G. A. P. D. S., \& Astika, I. B. P. (2017). Pengaruh Auditor's Professional Skepticism, Red Flags, Beban Kerja Pada Kemampuan Auditor dalam Mendeteksi Kecurangan (Studi Empiris pada Kantor Akuntan Publik Provinsi Bali). E-Jurnal Akuntansi, https:/ / doi.org/10.24843/EJA.2017.v21.i02.p11

Rachman, A. (2017). Pengaruh Etika Profesi,Skeptisisme Profesional, dan Pengalaman Kerja terhadap Kemampuan Mendeteksi Kecurangan Pada Auditor Internal Pemerintah [Universitas Lampung]. https://docplayer.info/67027955Pengaruh-etika-profesi-skeptisisme-profesional-dan-pengalaman-kerjaterhadap-kemampuan-mendeteksi-fraud-pada-auditor-internal-pemerintahskripsi.html

Rahmayani, L., Kamaliah, \& Susilatri. (2014). Pengaruh Kemampuan Auditor, Skeptisme Profesional Auditor, Teknik Audit dan Whistleblower Terhadap Efektivitas Pelaksanaan Audit Investigasi dalam Pengungkapan Kecurangan. Jom Fekom, 1(2), 1-15. https://jom.unri.ac.id/index.php/JOMFEKON/article/view/3946

Ranu, G. A. Y. N., \& Merawati, L. K. (2017). Kemampuan Mendeteksi Kecurangan Berdasarkan Skeptisme Profesional, Beban Kerja , Pengalaman Audit dan Tipe Kepribadian Auditor. JUARA: Jurnal Riset Akuntansi, 7(1), 79-90. 
https://jurnal.unmas.ac.id/index.php/JUARA/article/view/649 Sugiyono. (2017). Metode Penelitian Kuantitatif dan Kulitatif. Bandung: R\&D.

Suhardana, K. M. (2007). Tri Kaya Parisudha Bahan Kajian Untuk Berpikir Baik, Berkata Baik dan Berbuat Baik. Paramita : Surabaya. 